\title{
Boundary Marker (Kamień graniczny)
}

\author{
Author: Piotr Matywiecki
}

First Published: 1994

About the Author: Piotr Matywiecki was born in 1943 to the parents who had both escaped from the Warsaw Ghetto: Maria née Balut, a lawyer, and Anastazy Matywiecki, who was also a lawyer, as well as a social activist and poet, and who perished in the Warsaw Uprising (1944). In 1963, Matywiecki became a student of Polish philology at the University of Warsaw, but did not finish his studies, instead taking a job in 1968 at the Warsaw University Library, where he worked until 1987. In the early 1980s, Matywiecki helped to found the university Solidarity movement, publishing in underground literary journals and later working as deputy editor-in-chief of Tygodnik Literacki (1990-1991) and Potop (1991-1994, published as Przegląd Literacki, Literary Review, from 1992) then he started a cooperation with the Polish Radio.

Further Important Publications: Zdarte okładki (1965-2009) (2009, Ripped Covers; poems); Widownia (2012, The Audience; poems); Do czasu (2018, By the Time; poems); Dwa oddechy. Szkice o tożsamości żydowskiej i chrześcijańskiej (2010, Two Breaths: Essays on Jewish and Christian Identity; essays); Twarz Tuwima (2007, Tuwim's Face; biography).

\section{Content and Interpretation}

Piotr Matywiecki's monumental book is somewhat difficult to place in any genre. One may consider it an essay in four parts, each slightly different in form, with the characteristics of a philosophical treaty or anthology.

The first three parts of Boundary Marker are autobiographical, although they do not recount events from the author's life or invoke them only sparingly. Their autobiographical nature lies in the conclusions that Matywiecki draws from the conditions of his birth, creating a study of his consciousness and life as a "posthumous child of the Holocaust” (Matywiecki 1994, p. 13). More than once, he tries to describe the paradox of his existence: it is a life without life, life made impossible at its very outset, life gravitating towards the death and non-existence of a slain community, of which he considers himself a member. These first three sections - Shame, Empty Magic, and Three Treaties - are linked thematically, returning again and again, as Matywiecki points out, to the same issues, with the aim of showing their various different faces. It is important to note that these sections are presented in a different order than the one in which he wrote them. We know this as Matywiecki eagerly describes the circumstances of their elaboration, including the date and time of their creation in the narration itself, hoping to show how his thought processes wander, but also how his thoughts mature with regard to the expression of certain issues. His monologue be-

Ә Open Access. (๑) 2021 Anita Jarzyna, published by De Gruyter. (c) BY-NC-ND This work is licensed under a Creative Commons Attribution-NonCommercial-NoDerivatives 4.0 License.

https://doi.org/10.1515/9783110671056-012 
comes a critical, idiosyncratic analysis of the basic notions of discourse on the Holocaust, conducted through the lens of an intimate experience.

In each section, Matywiecki emphasises a different aspect of this combination. In Shame, he relates the eponymous shame to his radical style of expression, characterised by a form of exaggeration most evident in the recurring declarations of being "chained to death" (p. 13) of ghetto residents, and presented as a style the author finds impossible to overcome. This is also the shame of knowledge, emerging in the face of an uncrossable distance, and resulting in the shame of indifference, of the inevitable failure of his inquiries. Empty Magic is the author's way of calling the defence mechanism that involves blocking one's awareness of the suffering of people living in the Warsaw Ghetto, facilitated by the fact that the mass character of the Holocaust tends to obscure the individuality of - and in this way turn our attention away from the victims. In this part, Matywiecki enumerates and characterises the various symptoms and strategies of "external participation through thought" (p. 53) in the reality of the ghetto, which thus comes to receive a fictional status. According to Matywiecki, post-ghetto life of the post-humous child is also fictional. Three Treaties opens with a question regarding the emptiness left behind by Jewish inhabitants of Warsaw - an emptiness that is also a permanent lacuna in memory and language -, and proceeds to explore the notion of nothingness in this context. Among other things, Matywiecki tries to explain how the prewar collective imagination was already prepared for the possibility of the community's total annihilation. Central to all three sections is a reflection on the phenomenon of Warsaw, the status of a city that has lost its historical continuity, preserved only in its name (p. 95), and in which the memory of the annihilation of its Jewish residents has undergone a process of ritualisation - the very function of the ghetto in the collective imagination.

The last and most extensive section of Boundary Marker, with the title Sentences from the Ghetto, is composed of over a hundred passages of different length, each one describing various aspects of life in the Warsaw Ghetto and its functioning, and presenting key words that indicate different thematic categories such as: Walls, Street Dirt, Typhus, Gymnastics, Mass Emptiness, and the Death of Family Members. Each passage features quotes from journals and other documents from the Warsaw Ghetto, coupled with Matywiecki's inconclusive and meditative commentaries. This gesture gains special meaning in the context of the other parts of the book. Matywiecki tells us that this structure follows from his conviction that he has failed in the three previous attempts, in this way suggesting that the Holocaust testimonies resist all explanation. This is why, should we heed the call for an ethical reading, we would be best simply to quote the testimonies - to refrain from glossing the text or reducing it to aphoristic formulae.

\section{Main Topics and Problems}

Boundary Marker received extensive critical acclaim and is still considered an unprecedented and groundbreaking work in Polish literature on the Holocaust. Matywiecki 
wanted the book to be hermetic and challenging. It is for this reason that he debates with the notion of inexpressibility, a notion so highly revered in Holocaust studies of the 1990s and often simplified or overused as a pretext. For Matywiecki, meanwhile, the incomprehensibility and indescribability of the Warsaw Ghetto does not invalidate the necessity of undertaking the effort to express the Ghetto's reality and its modern conceptualisations. Matywiecki's monologue is uncompromising in its aim to deconstruct the rhetorical devices usually applied in reflections on the Holocaust. Matywiecki questions the discursive consensus and proves that our understanding of the reality of the Warsaw Ghetto is an illusion, the result of a kind of contract. It is in this way the language itself that resists, composed of meandering thoughts, based on paradoxes and contradictions, metaphors and neologisms. Language is not only the basic matter but also the overarching theme of Boundary Marker.

What gains particular importance in Matywiecki's essay is the notion of birthplace, which he implicitly reinterprets as the place of his conception that imposes an obligation on the writer, but also takes away his courage to live. It is therefore the continuously problematised and unstable position of the subject - the perspective projected by the narration - that is the main focus of Boundary Marker, a position that corresponds to the fallen and subsequently rebuilt status of the city of Warsaw with which it is emotionally "knit together" (Mach, 2016, pp. 319-321). Tomasz Łysak sees the title of the book (literally "boundary stone") as a reference to the author's identity (Łysak, 2004, p. 296; Mach, 2016, pp. 310, 323-324). This theory may raise objections, however, as the condition of the posthumous child is by definition exterritorial (Ubertowska, 2007, pp. 197-198). A more fitting interpretation therefore might be that the title indicates the quality of the Warsaw Ghetto as a liminal event, one that leaves behind material traces in the form of "dead stones" (Matywiecki, 1994, p. 91). In its finality, the Warsaw Ghetto lies beyond imagination and - as "ground zero" (p. 5) founds the postwar city of Warsaw and postwar consciousness. From the perspective of its reception, the title Boundary Marker appears self-referential: the book is a turning point in Holocaust discourse.

\section{Cited Works}

Krupa, B. (2013). Wobec nicości. Kamień graniczny. In: B. Krupa, Opowiedzieć Zagładę. Polska proza i historiografia wobec Holokaustu. Kraków: Universitas, pp. 249-276. Łysak, T. (2004). Trauma przedstawiona - trauma zapośredniczona: „Kamień graniczny“ Piotra Matywieckiego. In: W. Bolecki, R. Nycz, eds., Narracja itożsamość, vol. I. Narracja w kulturze. Warszawa: Wydawnictwo IBL, pp. 295-305. Mach, A. (2016). Postpamięć „pogrobowca“ Zagłady w „Kamieniu granicznym” Piotra Matywieckiego. In: A. Mach, Świadkowie świadectw. Postpamięć Zagłady w polskiej literaturze najnowszej. Torun: Wydawnictwo Uniwersytetu Mikołaja Kopernika, pp. 305-324. Matywiecki, P. (1994). Kamień graniczny. Warszawa: Latona. Ubertowska, A. (2007). Holokaust jako „wzorzec nieistnienia“ (Piotr Matywiecki, Sarah Kofman). In: A. Ubertowska, Świadectwo - trauma - głos. Literackie reprezentacje Holokaustu. Kraków: Universitas, pp. 187-207. 


\section{Further References}

Drewnowski, T. (1994). Najnowszy testament. Polityka, 35, p. 7. Komendant, T. (1995). Nicość. Twórczość, (2), p. 131. Leociak, J. (1994). Umarłe getto. Gazeta Wyborcza (appendix Książki no 9), 07.09., p. 4. Łukasiewicz, J. (1995). Dziedzictwo getta. Odra, (4), p. 115. Mikołejko, Z. (1994). Kamień graniczny. Ex Libris, 55, p. 8. Nasiłowska, A. (1994). Świadectwo wobec nicości. Res Publica Nowa, (9), p. 74. Pietrzak, R. (1995). Myślenie o Zagładzie. Nowe Książki, 1, p. 29. Szaruga, L. (1995). Dotykać nicości. Notatki z lektury „Kamienia granicznego”. Kultura (Paryż), (6), p. 143. Śpiewak, P. (1994). Kamień graniczny. Ex Libris, (55), p. 8. Umińska, B. (1994), W nieludzkiej ziemi. Gazeta Wyborcza (appendix Książki no 9), 07.09, p. 5. Zawistowska, W. (1994). Kamień graniczny. Stowo Żydowskie. Dos Jidisze Wort, (24), p. 17. 